\title{
THE LEVEL OF KNOWLEDGE OF, ATTITUDE TOWARD AND EMPHASIS GIVEN TO HBV AND HCV INFECTIONS AMONG HEALTHCARE PROFESSIONALS: DATA FROM A TERTIARY HOSPITAL IN TURKEY
}

\author{
AYHAN HILMI CEKIN ${ }^{1}$, YESIM CEKIN ${ }^{2}$, and AYGUL OZDEMIR ${ }^{3}$ \\ ${ }^{1}$ Antalya Training and Research Hospital, Antalya, Turkey \\ Department of Gastroenterology \\ ${ }^{2}$ Antalya Training and Research Hospital, Antalya, Turkey \\ Department of Microbiology \\ ${ }^{3}$ Antalya Training and Research Hospital, Antalya, Turkey \\ Department of Internal Medicine
}

\begin{abstract}
Objectives: To evaluate the level of knowledge of, to investigate the attitudes toward, and to determine the emphasis given to the national prevalence of HBV/HCV infections among healthcare professionals. Materials and Methods: A total of 206 healthcare professionals (mean (SD) age: 37.0 (6.3) years; 86.9\% - females) including medical laboratory technicians $(\mathrm{N}=54)$ and nurses $(\mathrm{N}=152)$ employed in the Antalya Training and Research Hospital, Antalya, Turkey. Laboratory $(\mathrm{N}=53)$, operating room $(\mathrm{N}=41)$ and in-patient clinic $(\mathrm{N}=112)$ staff were included in this descriptive study. A 33item questionnaire composed of questions related to their level of knowledge and attitudes toward HBV/HCV infections, the sources of their knowledge of HBV/HCV infections and the emphasis given to the national and global importance of the diseases was administered via a face-to-face interview method with each subject; participation was volunteer based. Results: The participants working in the in-patient clinic (18.0 (3.2)) had the highest mean (SD) knowledge level compared to the laboratory (16.4 (3.1), $\mathrm{p}<0.05)$ and operating room (17.0 (2.8), $\mathrm{p}<0.05)$ staff. The participants from the in-patient clinic $(44.6 \%)$ had a more advanced level of knowledge compared to the participants working in the laboratory $(27.8 \%$, $\mathrm{p}<0.05)$ and the operating room $(30.0 \%, \mathrm{p}<0.05)$. Most of the subjects $(60.7 \%)$ had education concerning HBV/HCV infections in the past. There was no significant difference between the hospital units in terms of the attitudes of healthcare workers (HCWs) toward HBV/HCV infections and the level of education concerning them. Conclusions: Our findings revealed a moderate level of knowledge in most HCWs, regardless of their exposure to risk. While the highest knowledge scores and vaccination rates were noted among the in-patient clinic staff, there was no significant difference between the hospital units in terms of the attitudes of HCWs towards a patient or a colleague with an HBV/HCV infection.
\end{abstract}

Key words:

Knowledge, Attitude, HBV infection, HCV infection, Healthcare workers

Received: January 20, 2012. Accepted: July 25, 2012.

Corresponding author: A.H. Çekin, Uluc Mah., 24. Cadde 1164 Sok., Sefik Aker Sitesi B Blok Daire: 10, Konyaaltı, Antalya, Turkey (e-mail: ayhancekin@hotmail.com). 


\section{INTRODUCTION}

The worldwide distribution of hepatitis B virus (HBV) infection varies widely by geographic region [1,2], ranging from $0.1 \%$ to $20 \%$ in different parts of the world $[1,3]$. Turkey was shown to have an intermediate endemic profile [4]. Studies from various centers in Turkey indicate $\mathrm{HBV}$ carrier rate of $4-15 \%$, yielding a risk of one out of every 10-20 people [5]. Concerning hepatitis C virus $(\mathrm{HCV})$ infection, it is estimated that $3 \%$ of the world population is infected with $\mathrm{HCV}$ [6]. The frequency of $\mathrm{HCV}$ in Turkey varies between $1.2 \%$ and $4 \%$ [7].

Based on the risk of exposure to blood and body fluids (BBF), HBV and HCV infections constitute a well-recognized occupational risk for healthcare workers (HCWs) [8-12].

According to the WHO reports, each year approximately three million of the overall 35 million HCWs worldwide experience percutaneous exposure to blood-borne viruses (BBVs) resulting in 16000 hepatitis $\mathrm{C}$ and 66000 hepatitis B infections, mainly from low-income countries [13] where a combination of increased risk, fewer safety precautions and inadequate risk reduction strategies were evident [14]. HCWs are known to have 2-4 fold risk of a hepatitis infection compared to the general population [15]. Occupational exposure is reported to have a huge negative impact on health systems resulting from depletion of human resources due to the loss of workers not only as a direct result of transmission, but also due to anxiety regarding safety [14]. In this context, based on the reported $\mathrm{HbsAg}$ positivity in $8.0 \%$ (3.5-16.4\%) and Anti-HBs positivity in 40.0\% (17.9-52.9\%) of HCWs in our country [16], screening HB$\mathrm{sAg}$ and anti-HBc as well as vaccination of the under-risk populations have been recommended [17,18].

Poor compliance and adherence to universal precaution (UP) standards by hospital management and HCWs as well as the lack of advanced knowledge of HCWs as health providers were considered among the factors that may constitute a major obstacle barring the implementation of preventive programs $[19,20]$.
Therefore, the present study was designed to examine the level of knowledge of the attitude toward and the emphasis given to $\mathrm{HBV}$ and $\mathrm{HCV}$ infections among healthcare professionals from a tertiary hospital in Turkey.

\section{METHODS}

\section{Study population}

Out of 240 healthcare professionals employed in the Antalya Training and Research Hospital, Antalya, Turkey, 206 healthcare professionals (85.8\%; mean (SD) age: 37.0 (6.3) years; $86.9 \%$ females) working in the laboratory $(\mathrm{N}=53)$, operating room $(\mathrm{N}=41)$, and in-patient clinic $(\mathrm{N}=112)$ were included in this descriptive study upon their voluntary participation.

A written informed consent was obtained from each subject following a detailed explanation of the objectives and the protocol of the study that was conducted in accordance with the ethical principles stated in the "Declaration of Helsinki" and approved by the institutional ethics committee.

\section{Data collection}

A 33-item questionnaire (see Appendix) composed of questions related to the level of knowledge of $\mathrm{HBV} / \mathrm{HCV}$ infections $(\mathrm{N}=25)$, attitudes toward $\mathrm{HBV} / \mathrm{HCV}$ infections $(\mathrm{N}=4)$, sources of knowledge on $\mathrm{HBV} / \mathrm{HCV}$ infections $(\mathrm{N}=3)$ and emphasis given to the national and global importance of the disease $(\mathrm{N}=1)$ was administered via a face-to-face interview method to each subject; participation was volunteer based.

The level of knowledge of HBV/HCV infections among healthcare professionals was evaluated through the answers given to 25 questions concerning the carriage, transmission, prevention and diagnosis of $\mathrm{HBV} / \mathrm{HCV}$ infections prepared in the "true", "false" and "do not know" format. Scoring was based on 1 point for each correct answer and 0 points for each incorrect answer. The overall score (range: 0-25) 
was determined based on the sum of correct answers given to 25 questions for each individual. The knowledge level was considered to be poor, moderate and advanced for a score of 0-7, 8-15 and 16-23, respectively.

The following four questions (items 26-29) were elaborated to measure the attitudes of healthcare professionals toward HBV/HCV. Questions 27 and 28 were Yes/No/ Uncertain question types, while question 29 included the choices of "clean with a disinfectant/admit to a department of infection diseases/nothing, since I am vaccinated/ other" with respect to the attitude.

The next three questions (items 30-32) examined the sources of knowledge on HBV/HCV infections, while the last item (item 33) was related to a scoring of the national importance given to $\mathrm{HBV} / \mathrm{HCV}$ infections according to the participants, based on a 1 to 10 rating scale, indicating low (ratings of 1-4), moderate (ratings of 5-7) and very high (ratings of 8-10) importance.

\section{Statistical analysis}

The statistical analyses were made using computer software (SPSS version 11.0, SPSS Inc. Chicago, IL, USA). The level of knowledge of HBV/HCV infections was determined based on the sum of the correct answers given to 25 questions by each individual. The average scores obtained for the level of knowledge were compared via One-way ANOVA and Chi-square $\left(\chi^{2}\right)$ tests. The distribution of data was described using "mean (standard deviation; SD)", minimum-maximum and percent (\%) where $\mathrm{p}<0.05$ was considered statistically significant.

\section{RESULTS}

\section{Demographic features, duration of employment and risk exposure among the participants}

The majority of our participants $(83.5 \%)$ were females, out of whom $26.2(\mathrm{~N}=54), 29.1(\mathrm{~N}=60)$ and $44.7 \%$ $(\mathrm{N}=92)$ worked in the laboratory, operating room and in-patient clinic, respectively. The duration of employment was identified to be $11-20$ years in $55.8 \%$ of the subjects. Vaccination against hepatitis was evident in $80.6 \%$ of the participants with the highest ratio identified for the participants working in the in-patient clinic $(87.0 \%)$, compared to the laboratory $(68.5 \%)$ and operating room $(81.7 \%)$ staff ( $p=0.024$, Table 1$)$. In terms of accidental punctures with contaminated needles, the risk exposure was evident in $47.1 \%$ of the participants with no significant differences in the ratios obtained with respect to each hospital unit (Table 1).

\section{Knowledge level of $\mathrm{HBV} / \mathrm{HCV}$ infections}

The participants working in the in-patient clinic (18.0 (3.2)) had the highest mean (SD) scores concerning the knowledge of $\mathrm{HBV} / \mathrm{HCV}$ infections compared to the laboratory $(16.4(3.1), \mathrm{p}<0.05)$ and operating room (17.0 (2.8), $\mathrm{p}<0.05)$ staff. The percentage of the participants with an advanced level of knowledge was higher in the in-patient clinic (44.6\%), compared to the laboratory $(27.8 \%, \mathrm{p}>0.05)$ and the operating room $(30.0 \%$, $\mathrm{p}>0.05)$ personnel, but without statistical significance (Table 2). There was no significant difference in the mean (SD) knowledge scores with respect to gender (20.9 (2.5) in females vs. 19.9 (2.4) in males, $p=0.60)$ and duration of employment $(20.6$ (2.5) for 1-10 years in practice, 20.5 (2.4) for 11-20 years and 21.4 (2.8) for $>21$ years, $p=0.142)$.

\section{Attitudes toward HBV/HCV infections}

There was no significant difference between the hospital units in terms of attitudes of healthcare workers toward HBV/HCV infections. The majority of the participants in each hospital unit declared that they would refer the patient with $\mathrm{HBV} / \mathrm{HCV}$ infections to an infectious diseases clinic $(90.7,93.3$ and $83.1 \%$ of the participants working in the laboratory, operating room and in-patient clinic, respectively; Table 3). 
Table 1. Demographic features, duration of employment and exposure risk among the participants according to the hospital units

\begin{tabular}{|c|c|c|c|c|}
\hline Parameters & $\begin{array}{l}\text { Laboratory } \\
(\mathrm{N}=54)\end{array}$ & $\begin{array}{l}\text { Operating room } \\
\qquad(\mathrm{N}=60)\end{array}$ & $\begin{array}{l}\text { In-patient clinic } \\
\quad(\mathrm{N}=92)\end{array}$ & $\mathrm{p}$ \\
\hline Age (years) $(\mathrm{M} \pm \mathrm{SD})$ & $38.9 \pm 7.2^{*}$ & $35.6 \pm 6.1$ & $36.7 \pm 5.5$ & $0.032^{\mathrm{a}}$ \\
\hline \multicolumn{5}{|l|}{ Gender (n, \%) } \\
\hline male & $24(37.0)$ & $10(16.7)$ & $0(0.0)$ & \multirow[t]{2}{*}{$>0.05$} \\
\hline female & $30(63.0)$ & $50(83.3)$ & $92(100.0)$ & \\
\hline \multicolumn{5}{|c|}{ Duration of work (years) (n, \%) } \\
\hline $1-10$ & $9(16.7)$ & $13(21.7)$ & $16(17.4)$ & \multirow{3}{*}{$>0.05$} \\
\hline $11-20$ & $24(44.4)$ & $35(58.3)$ & $56(60.9)$ & \\
\hline$\geq 21$ & $21(38.9)$ & $12(20.0)$ & $20(21.4)$ & \\
\hline \multicolumn{5}{|l|}{ Vaccination $(\mathrm{n}, \%)$} \\
\hline yes & $37(68.5)^{*}$ & $49(81.7)^{*}$ & $80(87.0)$ & \multirow[t]{2}{*}{$0.024^{\mathrm{b}}$} \\
\hline no & $17(31.5)$ & $11(18.3)$ & $12(13.0)$ & \\
\hline \multicolumn{5}{|l|}{ Exposure risk (n, \%) } \\
\hline yes & $22(59.3)$ & $25(41.7)$ & $50(54.3)$ & \\
\hline no & $39(72.2)$ & $35(58.3)$ & $42(45.7)$ & $>0.05^{\mathrm{b}}$ \\
\hline
\end{tabular}

* Statistically significant.

$\mathrm{M}$ - mean, SD - standard deviation.

${ }^{\text {a }}$ In the laboratory staff compared to the in-patient clinic staff (ANOVA test).

${ }^{\mathrm{b}} \chi^{2}$ test.

Table 2. The scores concerning the knowledge level based on the sum of correct answers about HBV/HCV infections among the participants

\begin{tabular}{lcccc}
\hline \multicolumn{1}{c}{ Knowledge about HBV/HCV } & $\begin{array}{c}\text { Laboratory } \\
(\mathrm{N}=54)\end{array}$ & $\begin{array}{c}\text { Operating room } \\
(\mathrm{N}=60)\end{array}$ & $\begin{array}{c}\text { In-patient clinic } \\
(\mathrm{N}=92)\end{array}$ & $\mathrm{p}$ \\
\hline Total score $(\mathrm{M} \pm \mathrm{SD})$ & $16.4 \pm 3.1$ & $17.0 \pm 2.8$ & $18.0 \pm 3.2$ & $0.041^{\mathrm{a}}$ \\
Range (min-max) & $6-23$ & $10-23$ & $7-23$ & \\
Level (n, \%) & & & & \\
$0-7$ (poor) & $1(1.9)$ & 0 & 0 & $>0.05^{\mathrm{b}}$ \\
$8-15$ (moderate) & $38(70.4)$ & $42(70.0)$ & $51(55.4)$ & \\
$16-23$ (advanced) & $15(27.8)$ & $18(30.0)$ & $41(44.6)$ & \\
\hline
\end{tabular}

${ }^{\text {a }}$ In other units compared to the in-patient clinic, ANOVA test.

${ }^{\mathrm{b}} \chi^{2}$ test.

Other abbreviations as in Table 1 .

Most of the participants stated that working with an individual with an $\mathrm{HBV} / \mathrm{HCV}$ infection in the same unit would not bother them (74.1, 75.0 and $60.9 \%$ of the participants working in the laboratory, operating room and in-patient clinic, respectively). The majority of the participants confirmed that they treat, collect or study blood samples of HBV/HCV patients (94.4, 93.3 and $86.9 \%$ of the participants working in the laboratory, 
Table 3. Distribution of attitudes toward HBV/HCV infections among the participants

\begin{tabular}{|c|c|c|c|}
\hline Attitude toward $\mathrm{HBV} / \mathrm{HCV}$ infections & $\begin{array}{c}\text { Laboratory } \\
(\mathrm{N}=54) \\
\mathrm{n}(\%)\end{array}$ & $\begin{array}{l}\text { Operating room } \\
(\mathrm{N}=60) \\
\mathrm{n}(\%)\end{array}$ & $\begin{array}{c}\text { In-patient clinic } \\
(\mathrm{N}=92) \\
\mathrm{n}(\%)\end{array}$ \\
\hline \multicolumn{4}{|c|}{ Which clinic do you refer a patient with an $\mathrm{HBV} / \mathrm{HCV}$ infection to? } \\
\hline infectious diseases & $49(90.7)$ & $56(93.3)$ & $82(83.1)$ \\
\hline internal medicine & $1(1.9)$ & $0(0)$ & $3(3.3)$ \\
\hline gastroenterology & $4(7.4)$ & $4(6.7)$ & $7(7.6)$ \\
\hline \multicolumn{4}{|c|}{ Do you feel disturbed if you work with an individual with hepatitis in the same unit? } \\
\hline yes & $8(14.8)$ & $8(13.3)$ & $16(17.4)$ \\
\hline no & $40(74.1)$ & $45(75.0)$ & $56(60.9)$ \\
\hline uncertain & $6(11.1)$ & $7(11.7)$ & $20(21.7)$ \\
\hline \multicolumn{4}{|c|}{ Do you treat or collect/study blood samples of a patient with an HBV/HCV infection? } \\
\hline yes & $51(94.4)$ & $56(93.3)$ & $80(86.9)$ \\
\hline no & $1(1.9)$ & $1(1.7)$ & $1(1.1)$ \\
\hline uncertain & $2(3.7)$ & $3(5.0)$ & $11(12.0)$ \\
\hline \multicolumn{4}{|c|}{ What is your reaction if you have accidental punctures with $\mathrm{HBV} / \mathrm{HCV}$ contaminated needles? } \\
\hline clean with a disinfectant & $15(27.8)$ & $16(26.7)$ & $16(17.4)$ \\
\hline consult the infectious diseases department & $33(61.1)$ & $34(56.7)$ & $67(72.8)$ \\
\hline nothing, since I am vaccinated & $3(5.6)$ & $4(6.7)$ & $5(5.4)$ \\
\hline other & $3(5.6)$ & $6(10.0)$ & $4(4.4)$ \\
\hline
\end{tabular}

$\mathrm{p}>0.05$.

operating room and in-patient clinic, respectively; Table 3).

Most of the participants declared that they consult the department of infectious diseases in case of accidental punctures with $\mathrm{HBV} / \mathrm{HCV}$-contaminated needles (61.1, 56.7 and $72.8 \%$ of the participants working in the laboratory, operating room and in-patient clinic, respectively; Table 3). There was no significant difference in the attitude toward $\mathrm{HBV} / \mathrm{HCV}$ infections including referral of the patient to another clinic ( $p=0.735)$, working with an individual with hepatitis in the same unit $(p=0.755)$, treating a patient with an $\mathrm{HBV} / \mathrm{HCV}$ infection $(\mathrm{p}=0.578)$ and the reaction in case of accidental punctures with $\mathrm{HBV} / \mathrm{HCV}$ contaminated needles $(\mathrm{p}=0.117)$ with respect to gender. Likewise, there was no significant difference in the attitude toward $\mathrm{HBV} / \mathrm{HCV}$ infections including referral of the patient to another clinic $(\mathrm{p}=0.233)$, working with an individual with hepatitis in the same unit $(\mathrm{p}=0.710)$, treating a patient with an HBV/HCV infection $(\mathrm{p}=0.582)$ and the reaction in case of accidental punctures with $\mathrm{HBV} / \mathrm{HCV}$ contaminated needles $(p=0.855)$ with respect to the duration of employment.

\section{Past education and source of information about HBV/HCV infections}

Past education concerning HBV/HCV infections was confirmed by most of the participants $(60.7 \%)$, with conventions and conferences $(37.9 \%)$ selected as the most common source of information. In total, $53.9 \%$ of the subjects identified their past education as insufficient. There was no significant difference between the hospital units in terms of past education about HBV/HCV infections (Table 4). 
Table 4. Past education concerning HBV/HCV infections and scores concerning the national importance given to $\mathrm{HB} / \mathrm{HCV}$ infections among the participants

\begin{tabular}{lcccc}
\hline \multicolumn{1}{c}{$\begin{array}{c}\text { Past education and importance given } \\
\text { to HBV/HCV infections }\end{array}$} & $\begin{array}{c}\text { Overall } \\
\mathrm{N}=206) \\
\mathrm{n}(\%)\end{array}$ & $\begin{array}{c}\text { Laboratory } \\
(\mathrm{N}=54) \\
\mathrm{n}(\%)\end{array}$ & $\begin{array}{c}\text { Operating room } \\
(\mathrm{N}=60) \\
\mathrm{n}(\%)\end{array}$ & $\begin{array}{c}\text { In-patient clinic } \\
(\mathrm{N}=92) \\
\mathrm{n}(\%)\end{array}$ \\
\hline $\begin{array}{l}\text { Education about HBV/HCV infections } \\
\text { yes }\end{array}$ & $125(60.7)$ & $27(50.0)$ & $37(61.7)$ & $61(66.3)$ \\
no & $34(16.5)$ & $12(22.2)$ & $10(16.7)$ & $12(13.0)$ \\
do not remember & $47(22.8)$ & $15(27.8)$ & $13(21.7)$ & $19(20.7)$ \\
Source of information & & & & \\
conference-convention & $78(37.9)$ & $16(42.1)$ & $25(61.0)$ & $37(56.1)$ \\
internet-newspaper & $20(9.7)$ & $10(26.3)$ & $3(7.3)$ & $7(10.6)$ \\
faculty lectures & $34(16.5)$ & $9(23.7)$ & $8(19.5)$ & $17(25.8)$ \\
high school lectures & $11(5.3)$ & $3(7.9)$ & $5(12.2)$ & $3(4.5)$ \\
family, friends & $2(1.0)$ & $0(0)$ & $0(0)$ & $2(3.0)$ \\
Do you find the extent of the past lectures on HBV/HCV infections adequate? & & & \\
yes & $48(23.3)$ & $12(22.2)$ & $14(23.3)$ & $22(23.9)$ \\
no & $111(53.9)$ & $33(61.1)$ & $31(51.7)$ & $47(51.1)$ \\
uncertain & $47(22.8)$ & $9(16.7)$ & $15(25.0)$ & $23(25.0)$ \\
The importance given to HBV/HCV infections in our country & & & $31(33.7)$ \\
low (ratings of 1-4) & $57(27.7)$ & $13(24.1)$ & $13(21.7)$ & $25(27.2)$ \\
moderate (ratings of 5-7) & $67(32.5)$ & $21(30.9)$ & $21(35.0)$ & $36(39.1)$ \\
very high (ratings of 8-10) & $82(39.8)$ & $20(37.0)$ & $26(43.3)$ & \\
\hline
\end{tabular}

$\mathrm{p}>0.05$.

The importance given to $\mathrm{HBV} / \mathrm{HCV}$ infections in Turkey is considered to be very high by $39.8 \%$ and moderate by $32.5 \%$ of the participants, with no significant difference between the hospital units in terms of the ratings (Table 4).

\section{DISCUSSION}

Findings concerning the knowledge about HBV/HCV infections among healthcare professionals working in a tertiary hospital in Turkey revealed a moderate degree of knowledge in most of the HCWs, regardless of the risk exposure, with the highest knowledge scores and vaccination rates among the in-patient clinic staff and similar high rates for appropriate attitudes towards a patient or a colleague with $\mathrm{HBV} / \mathrm{HCV}$ infections in the overall population.

The knowledge, awareness, and regulations regarding the protection of HCWs from blood-borne exposures were documented to be not satisfactory in the developing countries [12]. Likewise, the identification of a moderate degree of knowledge on $\mathrm{HBV} / \mathrm{HCV}$ in our study population composed in $26.2 \%$ of medical laboratory technicians and in $72.8 \%$ nurses is in line with the results of the first countrywide study from Turkey meant to address important aspects of the awareness about the risk of blood-borne infections and the use of protective barriers among HCWs. This indicates that not only the level of knowledge, but also 
the perception and approach manifested by some HCWs should be improved [20].

The identification of risk exposure in terms of accidental punctures with contaminated needles in almost half of the participants, with no significant difference in the ratios obtained with respect to the hospital units, is in line with the results of past studies conducted in tertiary hospitals in Turkey. The past history of accidental punctures with contaminated needles is indicated in $15.8 \%$ [21] and $90.3 \%$ [22] of HCWs and that of exposure to infected patients in 60.0 to $83.0 \%$ [23,24].

Although the probability of pathogen transmission was reported not to be a result of a single incident, but a number of exposures over time, combined with high prevalence of diseases [14], the confirmation of consulting the department of infectious diseases in case of accidental puncture with $\mathrm{HBV} / \mathrm{HCV}$-contaminated needles in more than two thirds of our HCWs emphasizes the value of immediate reporting of possible exposure risk in an estimation of real life exposure in daily clinical practice [25,26].

Nurses/midwives were reported to be at a greater risk for occupational exposure compared to other HCWs [27], and similar data from all around the world showed nurses to have more occupational injuries [28-31]. Surgical sites were shown to be a contributing variable since the splashing of BBF onto mucosal surfaces during the operation, injections, intravenous access, and blood draws was considered as a significant factor for the transmission of viral diseases [20]. Given the fact that surgical site personnel face more hazardous situations and working at the surgical site requires more compliance with the universal precautions [20], however not statistically significant, our finding of the higher knowledge level among HCWs employed in the in-patient clinic than in the operating room is rather notable.

Nevertheless, bearing in mind the high efficiency of transmission of hepatitis B virus and the frequent use of injections, most healthcare workers, even those in non-surgical departments, have been considered to be at a considerably high risk [19].

Similar positive attitudes towards a patient or a colleague with $\mathrm{HBV} / \mathrm{HCV}$ infections among our HCWs, regardless of the hospital unit, seems to be in line with the results of a past report indicating that $86 \%$ of the examined nurses stated that they treated each patient as if they were carrying a BBV (compared with $41 \%$ of the doctors) [32]. Since the available treatment for a hepatitis B virus infection does not provide a complete cure, prevention remains crucial [19]. While the differences in the HBV infection rates may reflect the disparities in the risk of exposure to this infection [19], the exposure risk of accidental punctures with contaminated needles was evident in $47.1 \%$ of the participants, with no significant difference with respect to the hospital unit.

Healthcare workers are known to have 2-4 fold risk of hepatitis infections compared to the general population [15]. Based on reported $\mathrm{HbsAg}$ positivity in $8.0 \%$ (3.5-16.4\%) and Anti-HBs positivity in 40.0\% (17.9$52.9 \%$ ) of HCWs in our country [16], the screening of HB$\mathrm{sAg}$ and anti-HBc, as well as vaccination of the under-risk populations have been recommended [17,18].

The limited access to vaccination in the group of HCW is associated with the lack of initiative on the part of the governments to formulate the policy and guidelines to ensure that all HCWs get vaccinated [19]. The vaccination rates among HCWs were reported to be low in the developing world, despite the fact that a safe, effective and highly acceptable HBV vaccine has been around since 1982 [19]. Laboratory technicians and nursing assistants had 12 and 18 times higher risk, respectively, of contracting a hepatitis infection than doctors [19], our findings in terms of the overall vaccination against hepatitis in $80.6 \%$ of the participants, compared to the reported vaccination rates of $38 \%$ among professional HCWs [33] are worth noting and comparable with other developing countries with the vaccination coverage of over $80 \%$ [19]. 
The identification of past education concerning $\mathrm{HBV} /$ HCV infections in $60.7 \%$ of HCWs in our study is comparable with the data from a past study concerning HCWs' compliance with the universal precautions in Turkey, indicating more than two-thirds of the participants to be trained in the prevention of blood-borne diseases and the risks of occupational injuries [20].

Since past education was stated to be insufficient by $53.9 \%$ of the HCWs who participated in our study, it can be stated that the education level about hepatitis and the compliance with UPs in the scope of preventing the transmission of blood-borne viruses are not excellent among HCWs in Turkey [20]. In a past study conducted in Turkey on the knowledge, behaviors and disinfection measures concerning hepatitis B among the healthcare personnel in emergency services, inappropriate attitudes and behavior of health personnel were reported to occur due to the lack of sufficient knowledge, and the need for continuous education and information about hepatitis B was then emphasized [34].

The emphasis given to HIV/AIDS in our county was considered to be very high by $39.8 \%$ and moderate by $32.5 \%$ of the participants, with no significant difference between the hospital units.

The identification of positive attitudes toward HBV/ $\mathrm{HCV}$ infections declared by the majority of our HCWs is in line with the statement that past education was not a significant factor for the compliance with UPs, whereas the training of HCWs would be one of the helpful ways to prevent occupational injuries and related infections [20].

Promoting the adherence to standard precautions has been considered as the best possible method of reducing the risk in resource-poor settings via the provision of simple equipment (such as gloves) and ensuring that the personnel members are trained in safe methods. While promoting adherence should play a large role in prevention strategies as a very cost-effective means of protecting against hepatitis, since vaccination only reduces the impact of $\mathrm{HBV}$ and vaccines against $\mathrm{HCV}$ have yet to be developed, more general protective measures should also be taken to protect against all blood-borne pathogens [14]. Standard precautions were documented to enable safe working environments that could help to minimize the employees' stress and discrimination against patients with HIV [14].

The findings concerning the knowledge about $\mathrm{HBV} / \mathrm{HCV}$ infections among healthcare professionals working in a tertiary hospital in Turkey revealed a moderate degree of knowledge in most of the examined HCWs, regardless of their exposure risk, with the highest knowledge scores and vaccination rates among the in-patient clinic staff; also similarly high rates for the appropriate attitudes of HCWs toward a patient or a colleague with an HBV/ $\mathrm{HCV}$ infection were found. Given the higher risk attributable to surgical departments and nurses, findings seem to emphasize the need for the immediate implementation of educational and legislative efforts in the scope of preventive methods protecting HCWs in order to minimize the risk of occupational exposure.

\section{ACKNOWLEDGEMENTS}

The authors would like to thank Prof. Şule Oktay, MD, PhD, and Cagla Ayhan, MD, from KAPPA Consultancy Training Research Ltd (Istanbul, Turkey), who provided the language revision of the manuscript.

\section{REFERENCES}

1. Yu MC, Yuan JM, Govindarajan S, Ross RK. Epidemiology of hepatocellular carcinoma [review]. Can J Gastroenterol 2000;8:703-9.

2. WHO. Immunization, vaccines and biologicals. Hepatitis $B$. Revised 2008 [cited 2011 Oct 10]. Available from URL: http:// www.who.int/vaccines/en/hepatitisb.html.

3. Lok AS, Mc Mahon BJ. Chronic hepatitis B: update 2009. Hepatol 2009;50:661-2. 
4. Tekay F. Seroprevalence of HBV, HCV and HIV in Hakkari province. Dicle Med J 2006;3:170-3 [in Turkish].

5. Turker T, Babayigit MA, Tekbas OF, Ogur R, Avcı IY, Pahsa A, et al. Frequency and distribution of hospitalizations due to viral hepatitis at Gulhane Military Medical Academy between 2002 and 2004. Gulhane Med J 2006;48:125-31 [in Turkish].

6. Te HS, Jensen DM. Epidemiology of hepatitis $B$ and $C$ viruses: A global overview. Clin Liver Dis 2010;14:1-21.

7. Sumer Z, Sumer H, Bakıcı MZ, Koc S. The evaluation in point of the HBsAg, anti-HCV, anti-HIVand syphilis of donor blood samples in Cumhuriyet University Medical Faculty Blood Center. J Viral Hepatitis 2000;7:330-2 [in Turkish].

8. Kermode M. Healthcare worker safety is a pre-requisite for injection safety in developing countries. Int J Infect Dis 2004;8: $325-7$.

9. Tarantola A, Koumare A, Rachline A, Sow PS, Diallo MB, Doumbia S, et al. A descriptive, retrospective study of 567 accidental blood exposures in healthcare workers in three West African countries. J Hosp Infect 2005;60:276-82.

10. Miceli M, Herrera F, Temporiti E, Li D, Vila A, Bonvehí P. Adherence to an occupational blood borne pathogens exposure management program among healthcare workers and other groups at risk in Argentina. Braz J Infect Dis 2005;9:454-8.

11. Beltrami EM, Williams IT, Shapiro CN, Chamberland ME. Risk and management of blood-borne infections in health care workers. Clin Microbiol Rev 2000;13:385-407.

12. Sagoe-Moses C, Pearson RD, Perry J, Jagger J. Risks to health care workers in developing countries. $\mathrm{N}$ Engl J Med 2001;345:538-41.

13. World Health Report 2002: Reducing risks, promoting healthy life [cited 2002 Oct 11]. Available from URL: http://www.who. int/whr/en.http://www.who.int/whr/2002/en/whr02_en.pdf.

14. Lee R. Occupational transmission of bloodborne diseases to healthcare workers in developing countries: meeting the challenges. J Hosp Infect 2009;72(4):285-91.

15. Sepkowitz KA. Nosocomial hepatitis and other infections transmitted by blood and blood products. In: Mandell GL, Bennett JE, Dolin R, editors. Principles and Practice of Infectious Diseases. 5th ed. New York: Churchill Livingstone; 2000. p. 3039-52.

16. Taşyaran MA. Epidemiology of HBV infection. In: Kılıçturgay K, Badur S, editors. Viral Hepatit 2001. 1st ed. İstanbul: Viral Hepatitis Society; 2001. p. 121-8 [in Turkish]. 17. Arısoy SA, Dinc G, Sanlıdag T, Tunger O, Ozbakkaloglu B. Hepatitis B and AIDS related knowledge, attitude and behaviors of students from Celal Bayar University Vocational School of Health Services and Manisa Vocational High School of Health Services. J Viral Hepatitis 1999;5:18 [in Turkish].

18. Gurcan S, Aydin O, Mistik R. Results of Hepatitis B vaccination. J Viral Hepatitis 2001;3:383-4 [in Turkish].

19. Chao J, Chang ET, So SK. Hepatitis B and liver cancer knowledge and practices among healthcare and public health professionals in China: a cross-sectional study. BMC Public Health 2010;10:98.

20. Hosoglu S, Akalin S, Sunbul M, Otkun M, Ozturk R; Occupational Infections Study Group. Healthcare workers' compliance with universal precautions in Turkey. Med Hypotheses 2011;77(6):1079-82.

21. Gucuk M, Karabey S, Yolsal N, Ozden YI. Percutaneous injuries in the health care personnel working in the general surgery clinics of the Medical School of Istanbul. Tur J Hosp Infect 2002;6:72-81 [in Turkish].

22. İnan D, Günseren F, Selçuk K, Harman R, Keskin S, Çolak D. Occupational exposure to blood and body fluids among healthcare workers in Akdeniz University. J Viral Hepatitis 2005;10:109-13 [in Turkish].

23. Cetin M, Temiz M, Aslan A, Turhan E. Determination of the knowledge levels on hepatitis $b$ virus of residents at Mustafa Kemal University Hospital. J Viral Hepatitis 2007; 12(3): 121-7 [in Turkish].

24. Akgul S, Gunduz T, Borand H, Ispir B, Ötnü AV. Evaluation of knowledge level about hepatitis $B$ and $H B V$ serological markers in healthcare workers. J Viral Hepatitis 2005;10:54-7 [in Turkish].

25. Moloughney BW. Transmission and postexposure management of bloodborne virus infections in the health care setting: Where are we now? Can Med Assoc J 2001;165:445-51. 
26. Sencan I, Sahin I, Ylldırım M, Yesildal N. Unrecognized abrasions and occupational exposures to blood-borne pathogens among health care workers in Turkey. Occup Med 2004;54:202-6.

27. Hosoglu S, Akalin S, Sunbul M, Otkun M, Ozturk R. Occupational Infections Study Group. Predictive factors for occupational bloodborne exposure in Turkish hospitals. Am J Infect Control 2009;37:65-9.

28. Kim LE, Evanoff BA, Parks RL, Jeffe DB, Mutha S, Haase $\mathrm{C}$, et al. Compliance with universal precautions among emergency department personnel: implications for prevention programs. Am J Infect Control 1999;27:453-5.

29. Mahoney FJ, Stewart K, Hu H, Coleman P, Alter MJ. Progress toward the elimination of hepatitis $B$ virus transmission among health care workers in the United States. Arch Intern Med 1997;157:2601-5.
30. Perry JHR. 5178 promises: unprecedented protection to US health care workers. Adv Exposure Prev 2000;5:39-44.

31. Turner HS, Hurley JL, Butler KM, Holl J. Accidental exposures to blood and other body fluids in a large academic medical center. J Am Coll Health 1999;47:199-206.

32. Stein AD, Makarawo TP, Ahmad MFR. A survey of doctors' and nurses' knowledge, attitudes and compliance with infection control guidelines in Birmingham teaching hospitals. J Hosp Infect 2003;54:68-73.

33. Clayton S, Yang H, Guan J, Lin Z, Wang R. Hepatitis B control in China: knowledge and practices among village doctors. Am J Public Health 1993;83(12):1685-8.

34. Malak AT, Celebi I, Celik GO, Turgay AS. Sener A, Kasapoglu Y. Knowledge, behaviors and disinfection measures about Hepatitis B of health personnel in emergency services and 112 emergency medical stations. Anatol J Clin Investig 2010:4(4):192-7.

This work is available in Open Access model and licensed under a Creative Commons Attribution-NonCommercial 3.0 Poland License - http://creativecommons.org/ licenses/by-nc/3.0/pl/deed.en. 